\title{
An improved model for the ikaite-glendonite transformation: evidence from the Lower Cretaceous of Spitsbergen, Svalbard
}

\author{
Madeleine Vickers', Matthew Watkinson², Gregory D. Price ${ }^{2} \&$ Rhodri Jerrett ${ }^{3}$ \\ ${ }^{1}$ St. Department of Geosciences and Natural Resource Management, Geology Section, Faculty of Science, University of Copenhagen, Øster Voldgade 10, \\ DK-1350 Copenhagen K, Denmark. \\ ${ }^{2}$ School of Geography, Earth and Environmental Sciences, Plymouth University, Plymouth, PL4 8AA, United Kingdom. \\ ${ }^{3}$ School of Earth and Environmental Sciences, University of Manchester, Williamson Building, Oxford Road, Manchester, M13 9PL, United Kingdom.
}

E-mail corresponding author (Madeleine Vickers): mlv@ign.ku.dk

\begin{abstract}
Glendonites, pseudomorphs after marine sedimentary ikaite, are found throughout the Lower Cretaceous succession of Svalbard. Existing models for the ikaite-to-glendonite transformation do not explain the different petrological fabrics observed in the glendonites of Lower Cretaceous Svalbard. This study presents an improved model for the formation of these glendonites, based on petrographic and geochemical observations, and published work on ikaite breakdown. We show that for the glendonites of Lower Cretaceous Svalbard, methane is unlikely to be the sole or indeed main driver behind their formation, and present an improved model for their formation that accounts for the varied petrographic fabrics observed in these particular glendonites. Coupled with our new model, stable isotope data demonstrate why bulk samples of ancient glendonite cannot be used for palaeotemperature reconstructions.
\end{abstract}

Keywords: Palaeoclimate; Early diagenesis; Glendonite; Early Cretaceous

Electronic Supplement: oxygen and carbon isotopic data

Received 22. November 2017 / Accepted 17. January 2018 / Published online 23. February 2018

\section{Introduction}

Glendonites are calcite pseudomorphs after the mineral ikaite, a metastable, hydrated form of calcium carbonate $\left(\mathrm{CaCO}_{3} \cdot 6 \mathrm{H}_{2} \mathrm{O}\right)$. Unlike other $\mathrm{CaCO}_{3}$ polymorphs, ikaite becomes more stable with decreasing temperatures (e.g., Marland, 1975; Bischoff et al., 1993; de Lurio \& Frakes, 1999), and for this reason the presence of glendonites in sedimentary rocks has been used to infer palaeo-cold water conditions (e.g., de Lurio \& Frakes, 1999; Selleck et al., 2007; Frank et al., 2008a, b; Price \& Nunn, 2010; Grasby et al., 2017). Ikaite requires specific chemical conditions to become metastable. This includes elevated alkalinity and phosphate concentrations (to inhibit calcite and aragonite growth), and low temperatures $\left(<8^{\circ} \mathrm{C}\right)$ (Suess et al., 1982; Bischoff et al., 1993; Buchardt et al., 2001; Swainson \& Hammond, 2001; Zhou et al., 2015). Furthermore, the experiments of Hu et al. (2014) with artificial seawater found that $\mathrm{pH}$ and salinity may also exert a strong control over ikaite precipitation.

Ikaite was first identified growing in tufa towers in the Ikka Fjord, SW Greenland, by Pauly (1963). Here, conditions for ikaite growth have been met due to highly alkaline spring water mixing with seawater (Buchardt et al., 2001). Ikaite has since been found growing in other environments where temperature, pressure and chemical conditions are suitable to stabilise ikaite and

Vickers, M., Watkinson, M., Price, G.D. \& Jerrett, R. 2018: An improved model for the ikaite-glendonite transformation: evidence from the Lower Cretaceous of Spitsbergen, Svalbard. Norwegian Journal of Geology 98, 1-15. https://dx.doi.org/10.17850/njg98-1-01. 
inhibit calcite/aragonite growth, including on Arctic and Antarctic sea ice (Dieckmann et al., 2008, 2010), and growing below the sediment-water interface in modern shelf settings (e.g., Suess et al., 1982; Schubert et al., 1997; Lu et al., 2012; Zhou et al., 2015). It is this marine sedimentary ikaite that pseudomorphs into the stellate calcite nodules now known as 'glendonites' (after those found in the Permian deposits of Glendon, New South Wales; Dana, 1849; David et al., 1905), which are found repeatedly in the sedimentary record, including the Lower Cretaceous succession of Svalbard (Maher et al., 2004; Price \& Nunn, 2010; Vickers et al., 2016).

Marine sedimentary ikaite is found in modern shelf settings between c. 3 and $20 \mathrm{~m}$ below the sedimentwater interface, around the sulphate-methane transition (Schubert et al., 1997; Lu et al., 2012), where porewater temperatures are $<8^{\circ} \mathrm{C}$ (Zhou et al., 2015). Two biogeochemical processes may provide the carbon source and specific chemical conditions necessary for marine sedimentary ikaite formation: (1) organic matter breakdown by sulphate reduction (Suess et al., 1982), and (2) oxidation of methane during sulphate reduction (Schubert et al., 1997; Rickaby et al., 2006; Teichert \& Luppold, 2013; Morales et al., 2017). Possible methane sources include methanogenesis (anaerobic microbial organic-matter breakdown) or the decomposition of solid methane hydrates (Schubert et al., 1997; Morales et al., 2017). The methane is believed to diffuse from a deeper source up through the sedimentary pile until it becomes oxidised at a redox barrier (Schubert et al., 1997; Greinert \& Derkachev, 2004; Morales et al., 2017; $\mathrm{Qu}$ et al., 2017). Both methane oxidation and organic matter breakdown occur in the sulphate reduction zone and result in the high carbonate alkalinity and high phosphate concentrations required for ikaite growth. Some authors imply that the oxidation of methane from methane seeps via methanotrophic microbes creates such favourable environments for glendonite formation that temperatures may have been elevated above the typical $<8^{\circ} \mathrm{C}$ (e.g., Teichert \& Luppold, 2013; Morales et al., 2017), and therefore the presence of glendonites in sedimentary successions is more useful as a palaeomethane seep indicator. As the $\delta^{13} \mathrm{C}$ value of ikaite reflects the $\delta^{13} \mathrm{C}_{\mathrm{DIC}}$ of the porewater carbon pool from which it grew (e.g., Lu et al., 2012; Teichert \& Luppold, 2013), methane-derived ikaite can be distinguished from that which had organic matter as its main carbon source.

There is much uncertainty about the ikaite-to-glendonite transformation, as the petrology of glendonite in thinsection suggests multiple phases of diagenetic growth, and the drivers behind these are debated (Swainson \& Hammond, 2001; Greinert \& Derkachev, 2004; Huggett et al., 2005; Selleck et al., 2007; Frank et al., 2008a, b; Teichert \& Luppold, 2013; Morales et al., 2017). This study sets out to assess whether this existing model for ikaite-to-glendonite transformation fits with the petrological and geochemical observations of the glendonites of Svalbard, and to improve or remodel this transformation according to these observations. Our model accounts for petrographic differences observed between the Rurikfjellet Formation and Carolinefjellet Formation glendonites, and highlights the potential pitfalls of using glendonites in quantitative palaeothermometric reconstructions. The results of this study have implications for the understanding of early diagenetic processes occurring below the sediment-water interface in the marine realm; informing the current understanding of regional-to-global geochemical and/or temperature trends in the Early Cretaceous.

\section{Geological setting}

During the Early Cretaceous, Spitsbergen, the largest island of the Svalbard archipelago, was located at c. $65^{\circ} \mathrm{N}$ and was part of a shallow epicontinental sea (Fig. 1A). Glendonites are found in the Lower Cretaceous of Svalbard, in the Hauterivian-Barremian-aged Kikutodden Member of the Rurikfjellet Formation (Price \& Nunn, 2010; Vickers et al., 2016) and upper Aptian-lower Albian of the Carolinefjellet Formation (upper Dalkjegla and Innkjegla members; Maher et al., 2004; Vickers et al., 2016). The Rurikfjellet Formation represents a regressive succession, moving from (oxic) open marine shelf environments in the lower Wimanfjellet Member to shallow-marine shelf deposits of the Kikutodden Member (Mørk et al., 1999; Vickers, 2017). The Kikutodden Member, which contains the glendonites, consists of coarsening-up packages of shale, mudstone, siltstone and sandstone, with siderite concretions common in the shale facies (e.g., Midtkandal et al., 2008; Vickers et al., 2016). The Carolinefjellet Formation was also deposited in open marine shelf conditions (e.g., Grundvåg \& Olaussen, 2017), and the glendonites are found in both the sand-rich Dalkjegla Member and shale-dominated, carbonate-concretionbearing Innkjegla Member (e.g., Krajewski \& Luks, 2003; Maher et al., 2004; Vickers et al., 2016). Glendonites were collected for this study from two sites on Spitsbergen; Festningen (Fig. 1B; $78^{\circ} 09.98^{\prime} \mathrm{N}, 13^{\circ} 94.32^{\prime} \mathrm{E}$ ), located on the southwestern side of Isfjorden; and the succession cropping out along the road between Longyearbyen airport and Longyearbyen itself, $78^{\circ} 13^{\prime} 32.88^{\prime \prime} \mathrm{N}$, $15^{\circ} 36^{\prime} 39.96^{\prime \prime}$ E (Fig. 1C), hereafter referred to as the Airport Road Section.

\section{Methods}

Careful bed-by-bed searches for glendonites were made in the studied outcrops at the Festningen and Airport Road sections (Fig. 1B, C). The locations of glendonite horizons were recorded via high-resolution conventional 

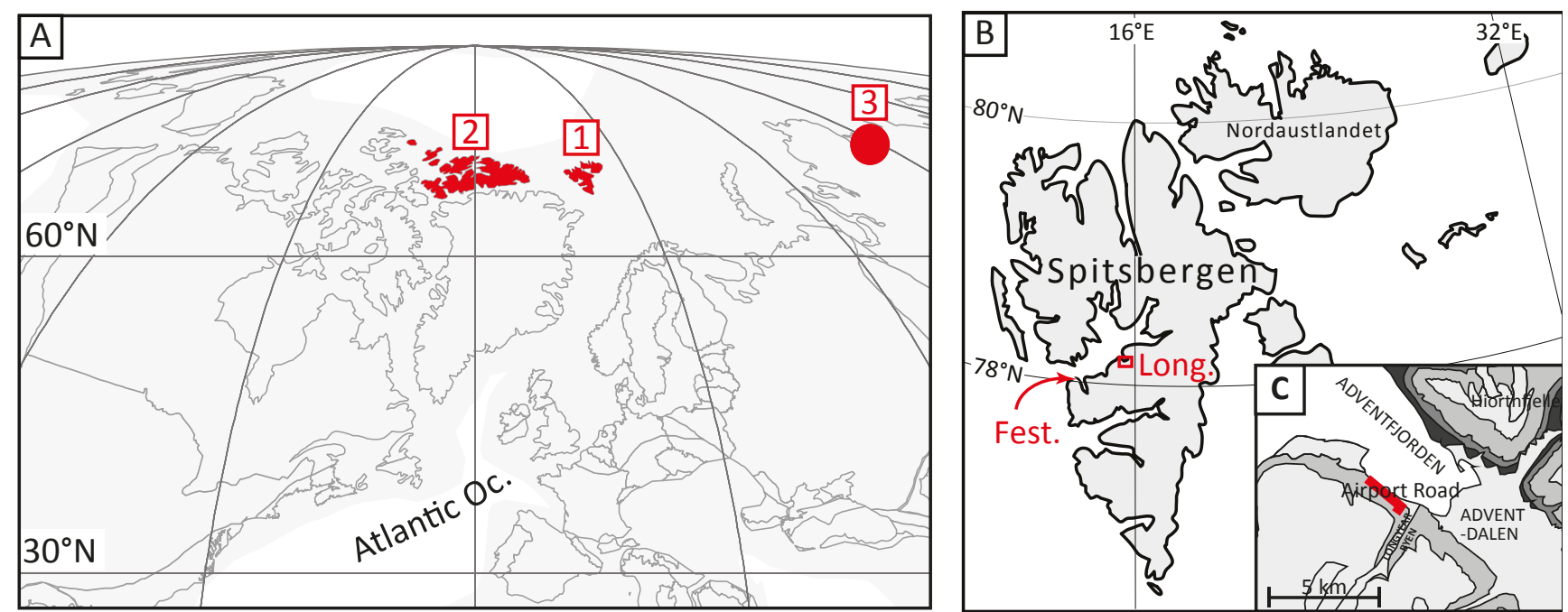

Figure 1. (A) The Early Cretaceous paleogeography for the northern hemisphere, taken from Boucot et al. (2013); 1 = Svalbard archipelago; $2=$ Queen Elizabeth Islands; 3 = northern Russian glendonite sites. (B) The figure shows the location of sites studied on Svalbard, indicated in red. Abbreviations: Long. - Longyearbyen; Fest. - Festningen; Oc. = Ocean. (C) Geological map of the area around Longyearbyen, redrawn from Major et al. (2000). Light grey = Carolinefjellet Formation; grey = Helvetiafjellet Formation; dark grey = Rurikfjellet Formation. Airport Road Section indicated as red line.

graphic logging, and whole glendonites were sampled from each glendonite horizon (Vickers, 2017).

Carbon and oxygen isotope analysis of the bulk glendonites was performed at Plymouth University using an Isoprime isotope ratio mass-spectrometer using $~ 0.5$ $\mathrm{mg}$ of powdered sample. Carbon and oxygen isotope ratios are expressed in standard delta notation as per mil (\%) deviation from the Vienna Pee Dee Belemnite (VPDB) standard. Measured results were calibrated against USGS standards (NBS19, CO8 and CO9).

Polished thin-sections were examined using a polarising light microscope, and cathodoluminescence (CL) petrography was performed using a CL8200 Mk5-2 Optical CL System, operating at an accelerating voltage of $\leq 25 \mathrm{kV}$ and current of $\leq 400-500 \mu \mathrm{A}$. Selected thinsections were examined using a JEOL 7001 FESEM at Plymouth University Electron Microscopy Centre at $20 \mathrm{kV}$ with a working of $10 \mathrm{~mm}$ using the backscatter electron detector.

\section{Results}

\section{Sedimentary and stratigraphic location of glendonite horizons}

Altogether, 8 glendonite horizons were identified in the Festningen Section, and 2 horizons identified in the Airport Road Section (Fig. 2; Table 1).

In the Festningen Section, 3 glendonite horizons were found in the Kikutodden Member of the Rurikfjellet Formation, at $409 \mathrm{~m}, 411 \mathrm{~m}$ and $441 \mathrm{~m}$. Glendonites of the Carolinefjellet Formation were found in 6 horizons between 655 and $753.15 \mathrm{~m}$ at Festningen, and at $2.5 \mathrm{~m}$ and 118-199 $\mathrm{m}$ in the succession at the Airport Road Section. This correlates to c. $602 \mathrm{~m}$ in the Festningen Section (Vickers, 2017), stratigraphically lower than the glendonite horizons of the Carolinefjellet Formation at Festningen. All the glendonites described in this study were found in sandstone or siltstone, all in fully marine facies associations, ranging from the proximal offshore transition zone through to (proximal) open marine shelf (Vickers 2017; Table 1). The depositional environment for the sediments in which the glendonites are found is consistently below fair-weather wave base, for all glendonite horizons, sometimes ranging to just below storm wave base. This constrains the minimum depth of glendonite formation to below that of storm wave base, which is on the scale of tens of metres.

\section{Shape}

The glendonites collected may be grouped according to their physical shape, although it is noted that all reflect single or combinations of the bipyramidal, elongate ikaite crystal shape (e.g., Suess et al., 1982; Schubert et al., 1997; Lennie et al., 2004; Rickaby et al., 2006; Lu et al., 2012; Hu et al., 2014). The glendonites collected from the Lower Cretaceous of Spitsbergen tend to be rosette in form (composed of many intersecting blades; Table 1; Fig. 3A, H \& K). These rosettes may be slightly flattened (Fig. 3D), or may be found inside carbonate concretions (e.g., Fig. 3G \& H), where they may be cylindrical (Fig. 
$3 G)$. In some horizons, the glendonites were larger and broke into pieces during collection (broken aggregates of radiating blades, described in Table 1 as 'partial rosette'; Fig. 3B, C \& E). They appear to have broken from the centre outwards (half-blades; no full blades preserved). Some glendonites appear as single or double blades (Fig. 3I \& J).

\section{$\delta^{13} \mathrm{C}$ and $\delta^{18} \mathrm{O}$ analysis}

For the bulk glendonite data the maximum $\delta^{13} \mathrm{C}$ value was $-30.9 \%$ for APT2.2c; a glendonite from the horizon at $2.2 \mathrm{~m}$ in the Airport Road Section, and the minimum $\delta^{13} \mathrm{C}$ value was $-13.3 \%$ for FST753.15, a glendonite from the horizon at $753.15 \mathrm{~m}$ in the Festningen Section (Fig. 4A). The minimum $\delta^{18} \mathrm{O}$ value was $-12.3 \%$ for FST411.2 (horizon $411.2 \mathrm{~m}$ in the Festningen Section), and the maximum $\delta^{18} \mathrm{O}$ value was -1.0 for APT2.2c (horizon 2.2 $\mathrm{m}$ in the Airport Road Section; Fig. 4A). The glendonites from the Rurikfjellet Formation (Hauterivian-Barremian aged) show a wider spread in $\delta^{18} \mathrm{O}$ values than those from the Late Aptian Carolinefjellet Formation (Fig. 4A); from -12.3 to $-2.8 \%$ o (range of $9.5 \%$; mean of $-8.8 \%$ ) vs. -7.6 to $-1.0 \%$ (range of $6.6 \%$, mean of $-5.7 \%$ ). The $\delta^{18} \mathrm{O}$ and $\delta^{13} \mathrm{C}$ data show a negative correlation, $\mathrm{r}^{2}=0.52$ (Fig. 4B).

Internal structure
The glendonites show a range of internal structures, from (a) mm-scale zoning on each blade of calcite (hereafter referred to as macrozoned; Fig. 5A, B); (b) core or rim evident but otherwise no apparent zonation (Fig. 5C, D); or (c) homogeneous across centre to edge of the glendonite (hereafter referred to as unzoned; Fig. 5E, F). Under light-microscope, CL and SEM, the microstructure can be seen (Fig. 6). In addition to calcite, pyrite is observed, and some show areas of siliceous silt inclusions. Different calcite morphologies are evident, interpreted as representing different generations of calcite (also identified in glendonites from a variety of locations by David et al., 1905; Boggs, 1972; Larsen, 1994; McLachlan et al., 2001; Huggett et al., 2005; Selleck et al., 2007; Teichert \& Luppold, 2013) (Fig. 6). The different calcite types are described below:

Type I: small, subrounded to lath-shaped, light brown to grey (due to inclusions) calcite crystals. These are commonly zoned or with a clear rim/core, and may have an irregular outline (Fig. 6A). Type I calcite is often inclusion-rich, particularly in the cores, and under CL is brightly luminescent with non-luminescent zones (Fig. 6B). These non-luminescent zones are interpreted as ferroan (e.g., after Barnaby \& Rimstidt, 1989; Machel \& Burton, 1991).

Type II: brown calcite, zoned. This grows from the surface of Type I grains, and may be lobate or botryoidal (Fig. 6A,

Table 1. Descriptions of the glendonite horizons identified in this study, along with descriptions of the glendonites found in each horizon.

\begin{tabular}{|c|c|c|c|c|c|c|}
\hline Sample ID & Horizon & Host lithology & Shape & Size $(\mathrm{cm})$ & Structure & Comments \\
\hline $\begin{array}{l}\text { FST408- } \\
\text { FST409 }\end{array}$ & $\begin{array}{l}\text { Festningen } \\
408-409 \mathrm{~m}\end{array}$ & Siltstone & Rosette & $1-2$ & Macrozoned & $\begin{array}{l}\text { Top (weathered) surface rust coloured, } \\
\text { 'spider-web' pattern }\end{array}$ \\
\hline $\begin{array}{l}\text { FST411- } \\
\text { FST412 }\end{array}$ & $\begin{array}{l}\text { Festningen } \\
411-412 \mathrm{~m}\end{array}$ & Siltstone & $\begin{array}{l}\text { Cylindrical } \\
\text { rosette }\end{array}$ & $\begin{array}{l}2-3.5 \text { diameter } \\
1-2.5 \text { thickness }\end{array}$ & Macrozoned & $\begin{array}{l}\text { Top (weathered) surface rust coloured, } \\
\text { 'spider-web' pattern }\end{array}$ \\
\hline $\begin{array}{l}\text { FST441- } \\
\text { FST442 }\end{array}$ & $\begin{array}{l}\text { Festningen } \\
441-442 \mathrm{~m}\end{array}$ & Siltstone & $\begin{array}{l}\text { Partial rosette, } \\
\text { Rosette }\end{array}$ & $4-5$ & Macrozoned & \\
\hline FST655 & $\begin{array}{l}\text { Festningen } \\
655 \mathrm{~m}\end{array}$ & $\begin{array}{l}\text { Hummocky cross- } \\
\text { stratified sandstone }\end{array}$ & Rosette & $1.5-5$ & $\begin{array}{l}\text { Rim and } \\
\text { core, no } \\
\text { macro-zoning }\end{array}$ & $\begin{array}{l}\text { Range of size and shape. Smaller ones are } 1.5 \\
\mathrm{~cm} \text {, flattened. }\end{array}$ \\
\hline FST699.5 & $\begin{array}{l}\text { Festningen } \\
699.5 \mathrm{~m}\end{array}$ & $\begin{array}{l}\text { Heterolithic } \\
\text { siltstone-sandstone }\end{array}$ & $\begin{array}{l}\text { Rosette } \\
\text { (flattened) }\end{array}$ & $1-2 \times 0.5-1$ & $\begin{array}{l}\text { Not zoned, } \\
\text { poss. core }\end{array}$ & $\begin{array}{l}\text { Rust-coloured weathered surface. } \\
\text { Displacive growth in sediment pile. }\end{array}$ \\
\hline FST708.5 & $\begin{array}{l}\text { Festningen } \\
708.5 \mathrm{~m}\end{array}$ & $\begin{array}{l}\text { Heterolithic } \\
\text { siltstone-sandstone }\end{array}$ & $\begin{array}{l}\text { Rosette } \\
\text { (flattened) }\end{array}$ & $2.5-3.5$ & Zoned & \\
\hline FST724.5 & $\begin{array}{l}\text { Festningen } \\
724.5 \mathrm{~m}\end{array}$ & $\begin{array}{l}\text { Hummocky cross- } \\
\text { stratified sandstone }\end{array}$ & Rosette & $0.5-1$ & Not zoned & $\begin{array}{l}\text { Beige; in darker host sed. 'coarse' appearance } \\
\text { compared to host sed. }\end{array}$ \\
\hline FST740 & $\begin{array}{l}\text { Festningen } \\
740 \mathrm{~m}\end{array}$ & Siltstone-sandstone & $\begin{array}{l}\text { Cylindrical, } \\
\text { not rosette } \\
\text { form }\end{array}$ & $2 \times 2 \times 1$ & $\begin{array}{l}\text { Totally } \\
\text { homogeneous }\end{array}$ & $\begin{array}{l}\text { May not be glendonite horizon; does not } \\
\text { resemble other glendonites. }\end{array}$ \\
\hline FST753 & $\begin{array}{l}\text { Festningen } \\
753 \mathrm{~m}\end{array}$ & Siltstone & $\begin{array}{l}\text { Rosette } \\
\text { (flattened) }\end{array}$ & $4.5 \times 3$ & Core \&/or rim & \\
\hline $\begin{array}{l}\text { APT2.1- } \\
\text { APT2.5 }\end{array}$ & $\begin{array}{l}\text { Airport } \\
\text { Road Lower } \\
2-2.5 \mathrm{~m}\end{array}$ & Siltstone-sandstone & $\begin{array}{l}\text { Rosettes, } \\
\text { cylindrical } \\
\text { rosettes, } \\
\text { partial rosette }\end{array}$ & $\begin{array}{l}3-4 \text { rosette } \\
2-4 \text { blades }\end{array}$ & Core \&/or rim & $\begin{array}{l}\text { Pyritised cores in ones within cylindrical } \\
\text { nodules }\end{array}$ \\
\hline ABS22 & $\begin{array}{l}\text { Airport } \\
\text { Road Upper } \\
118-119 \mathrm{~m}\end{array}$ & Siltstone-sandstone & $\begin{array}{l}\text { Rosettes, } \\
\text { partial rosettes, } \\
\text { blades }\end{array}$ & $\begin{array}{l}3-4 \text { rosette } \\
2-3 \text { blades }\end{array}$ & Not zoned & $\begin{array}{l}\text { v. lumpy, shape indistinct, often broken/in } \\
\text { bits }\end{array}$ \\
\hline
\end{tabular}




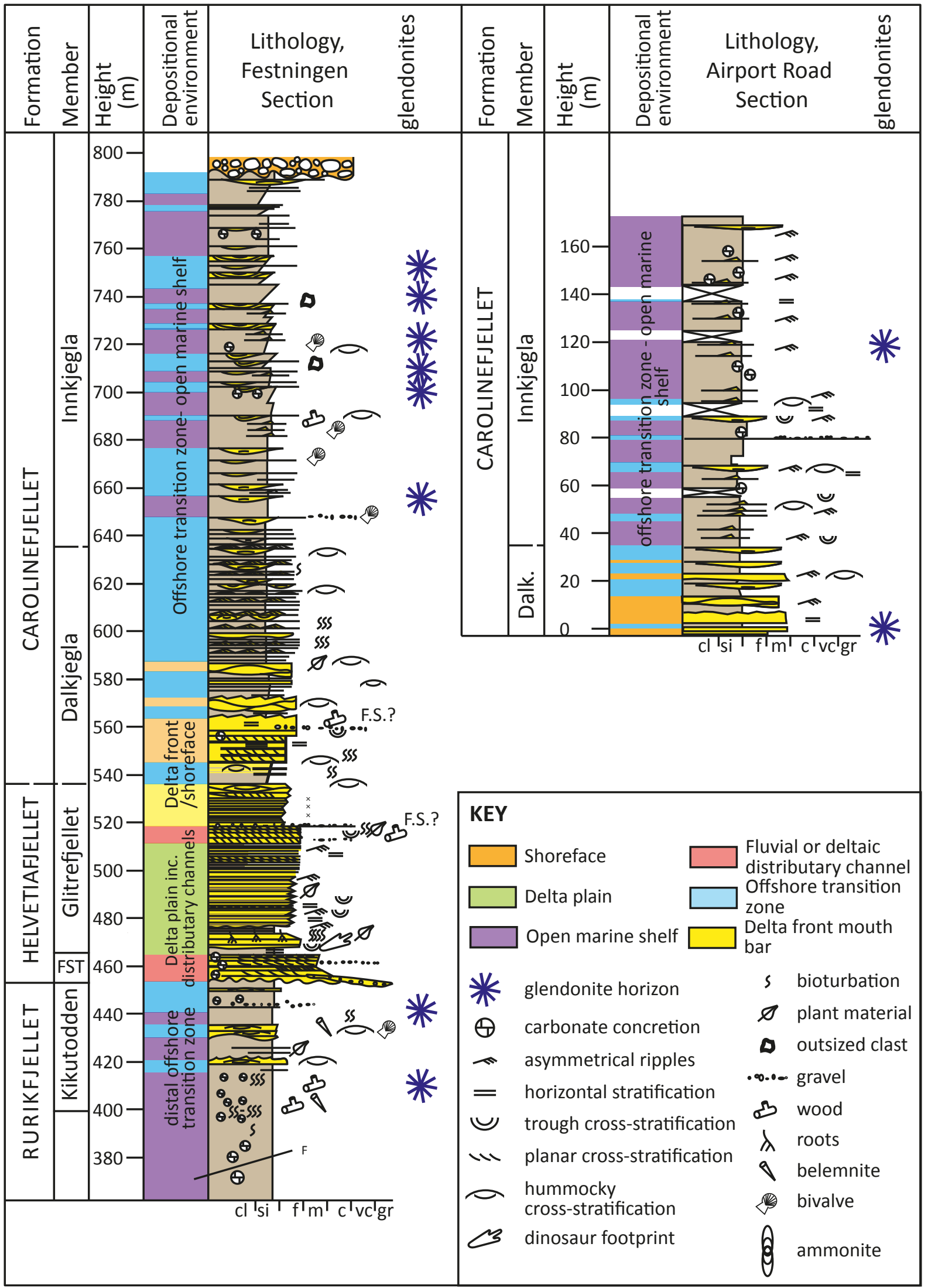

Figure 2. The sedimentary location of glendonites in the Festningen and Airport Road sections. Log of the Festningen Section modified after Vickers et al. (2016). Lithostratigraphy, facies associations and interpreted depositional environments are also shown. Abbreviations: FST. Festningen Member; Dalk. - Dalkjegla Member; F.S. - Flooding Surface. 


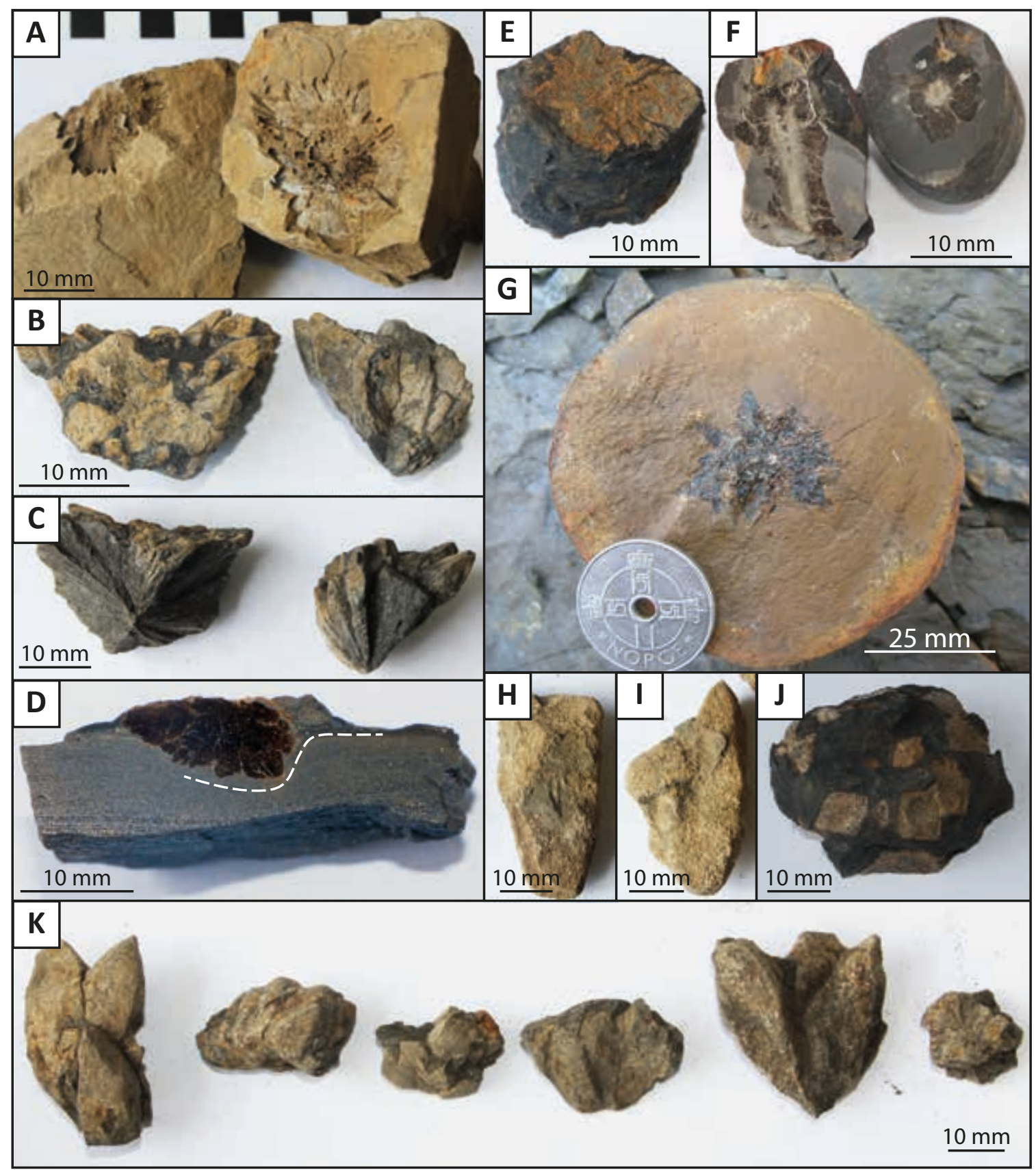

Figure 3. The figure shows the range of shapes of glendonites sampled from the Festningen and Airport Road sections. (A) Rosette form glendonite from $655 \mathrm{~m}$ in the Festningen Section, poor preservation. (B) \& (C) Partial rosette glendonites from the Festningen Section, horizon $441.25 \mathrm{~m}$ (photographs of opposite sides of the glendonites,; mm-scale zoning just visible. (D) Flattened rosette form glendonite from $699.5 \mathrm{~m}$ in the Festningen Section. Sediment distorted around glendonite, distorted layer highlighted by dashed white line. (E) Festningen Section, glendonite horizon at $411.6 \mathrm{~m}$, cylindrical rosette form. (F) Cylindrical rosette glendonites inside concretion, with distinct pyritised core, from $2.2 \mathrm{~m}$ in the Airport Road Section. (G) Rosette glendonite inside concretion. (H) \& (I) Bladed glendonites from the Airport Road Section, horizon at 118-119 $m$, blades. (J) Rosette glendonites from horizon at 118-119 $m$ of the Airport Road Section. (K) Glendonites from $2.2 \mathrm{~m}$ in the Airport Road Section; partial rosette forms.

D). Type II calcite is less luminescent than Type I (Fig. $6 \mathrm{~B})$, suggesting that it has a higher overall iron content. Under CL, Type II is observed to alternate between thin zones of luminescence and non-luminescence, with increasingly non-luminescent calcite towards the outer edge (Fig. 6D), suggesting increasing iron enrichment towards the outer edge. Quite commonly the boundary between type II and III calcite appears etched (Fig. 6A, B, $\mathrm{D} \& \mathrm{E})$.

Type III: brown or transparent calcite spar, infilling pore space (Fig. 6A). Type III calcite is mostly nonluminescent (Fig. 6B), suggesting that it is ferroan (e.g., Machel \& Burton, 1991). 


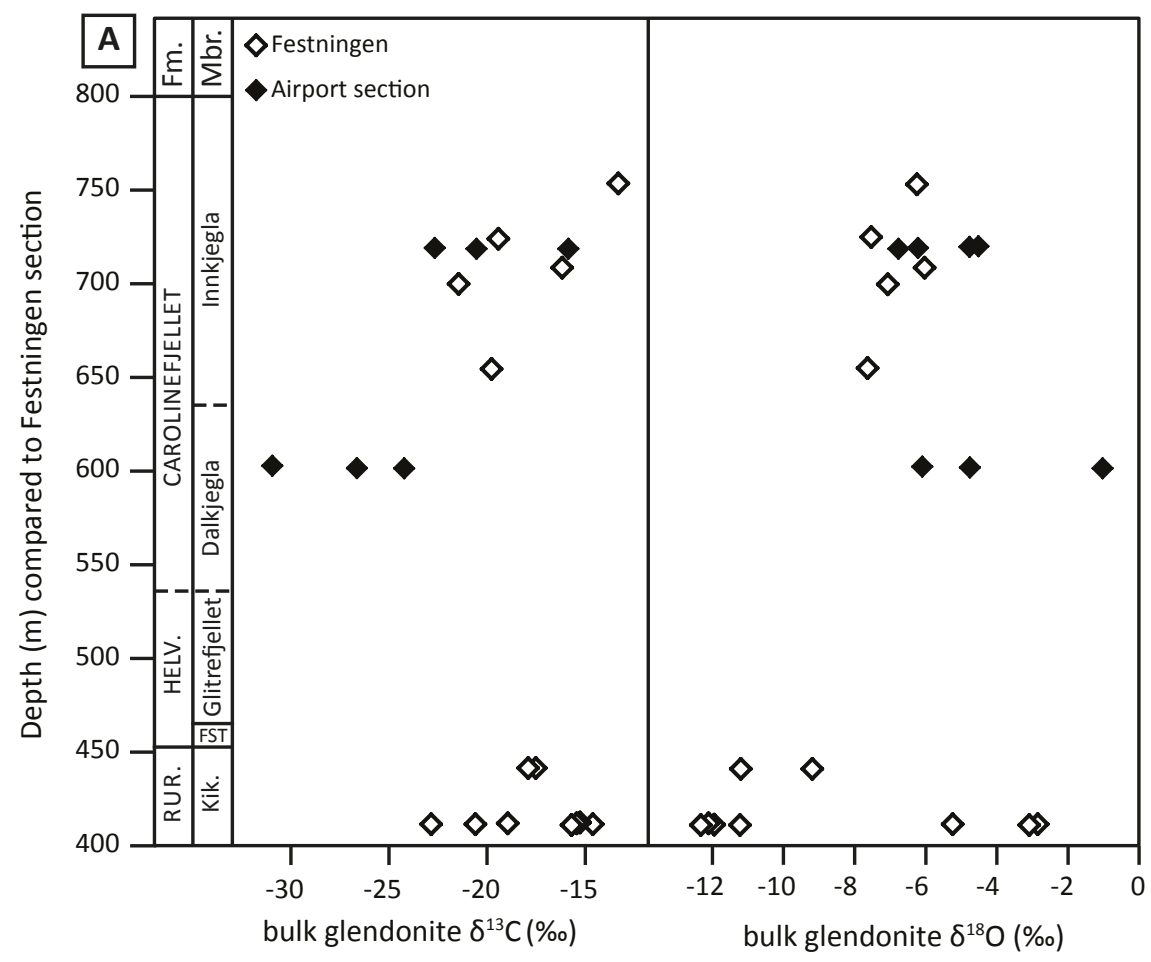

B

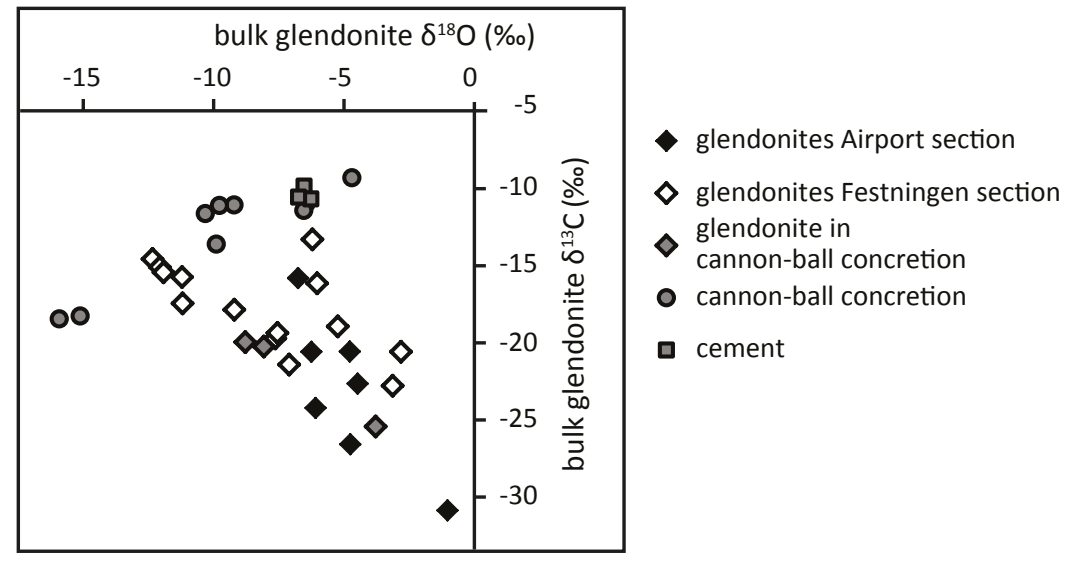

Figure 4. (A) The bulk glendonite $\delta^{13} \mathrm{C}$ and $\delta^{18} \mathrm{O}$ results plotted against stratigraphic height in the Festningen Section (see Electronic Supplement for sample names and values). Glendonites from the Airport Road Section are shown in black diamonds, using the chemostratigraphic and sequence-stratigraphic correlation to the Festningen Section of Vickers (2017). (B) The bulk glendonite $\delta^{18} O$ plotted against bulk glendonite $\delta^{13} \mathrm{C}$ from glendonites of the Festningen Section (white diamonds), and those of the Airport Road Section (black diamonds). $\delta^{13} \mathrm{C}$ and $\delta^{18} \mathrm{O}$ data for a glendonite in a carbonate (cannon-ball) concretion, along with data for the concretionary calcite and matrix, shown in grey (diamonds, circles and squares, respectively). The negative correlation between $\delta^{13} \mathrm{C}$ and $\delta^{18} \mathrm{O}$ for the glendonites is clear. Abbreviations: RUR. - Rurikfjellet; Kik. - Kikutodden; HELV. - Helvetiafjellet; FST - Festningen; Fm. - Formation; Mbr. - Member

\section{Discussion}

\section{Sedimentological context}

The depositional environment for both the Kikutodden Member and the Carolinefjellet Formation ranges from the proximal offshore transition zone through to open marine shelf facies associations (Vickers, 2017) (Fig. 2). This is consistent with the location of modern marine sedimentary ikaite, which is found in marine shelf environments in the high latitudes (e.g., Antarctic Peninsula, Laptev Sea continental margin; Suess et al., 1982; Schubert et al., 1997; Zhou et al., 2015). The observations that the sediments surrounding the glendonites are deformed around the pseudomorphs (e.g., Fig. 3D; also observed by Greinert \& Derkachev, 2004; Huggett et al., 2005; Selleck et al., 2007; Frank et al., 2008a, b), and the occurrence of glendonites in horizons with cannon-ball concretions (and, in a few cases inside concretions, Fig. $3 \mathrm{G}, \mathrm{H}$ ), suggest that the ikaite transformed to glendonite whilst the sediment 


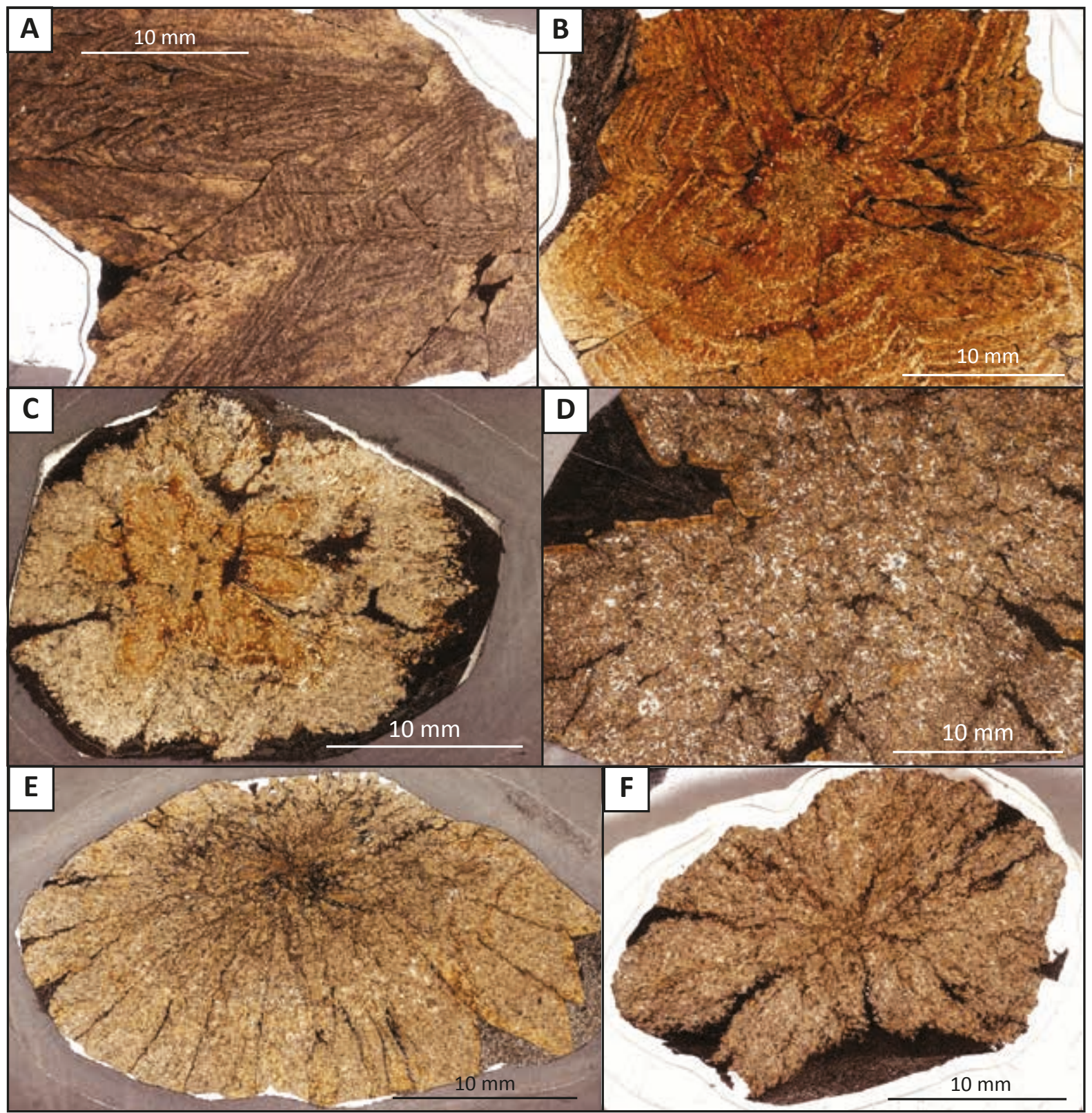

Figure 5. Photomicrographs of thin-sections showing the internal structure of glendonites (zoned, core/rim, unzoned). (A) Macro-zoned glendonite FST441.25, from $441.25 \mathrm{~m}$ in the Festningen Section. (B) Macrozoned glendonite FST411.5C, from $411.5 \mathrm{~m}$ in the Festningen Section. (C) Glendonite APT2.2, showing distinct core, from $2.2 \mathrm{~m}$ in the Airport Road Section. (D) Glendonite FST753.15, from $753.15 \mathrm{~m}$ in the Festningen Section, showing a narrow rim, inside unzoned. High percentage of clear calcite spar. (E) Unzoned flattened rosette glendonite, FST655, from $655 \mathrm{~m}$ in the Festningen Section. (F) Glendonite ABS22 from 118-119 m in the Airport Road Section. The core is slightly distinct from the rest of the glendonite.

was uncompacted and still in the sulphate reduction zone (where it is believed the ikaite grew; Suess et al., 1982; Schubert et al., 1997; Rickaby et al., 2006; Teichert \& Luppold, 2013). This is consistent with Krajewski \& Luks (2003) who also suggested that the cannon-ball carbonate concretions in the Innkjegla Member of the Carolinefjellet Formation, Svalbard, formed in the upper part of the sulphate reduction zone, where the microbial oxidation of organic matter provides the carbon source for calcite precipitation.
The key difference between the Carolinefjellet Formation and Kikutodden Member glendonite horizons is that sedimentation rates appear to have been much higher in the Carolinefjellet Formation than in the Kikutodden Member. This is suggested by both the improved chemostratigraphy of Vickers et al. (2016) for the Kikutodden Member, and the fact that more intense bioturbation, more fossil material and carbonate concretions occur in the Kikutodden Member than in the Carolinefjellet Formation (Fig. 4). The lower sedimentation rates in the Kikutodden Member mean 

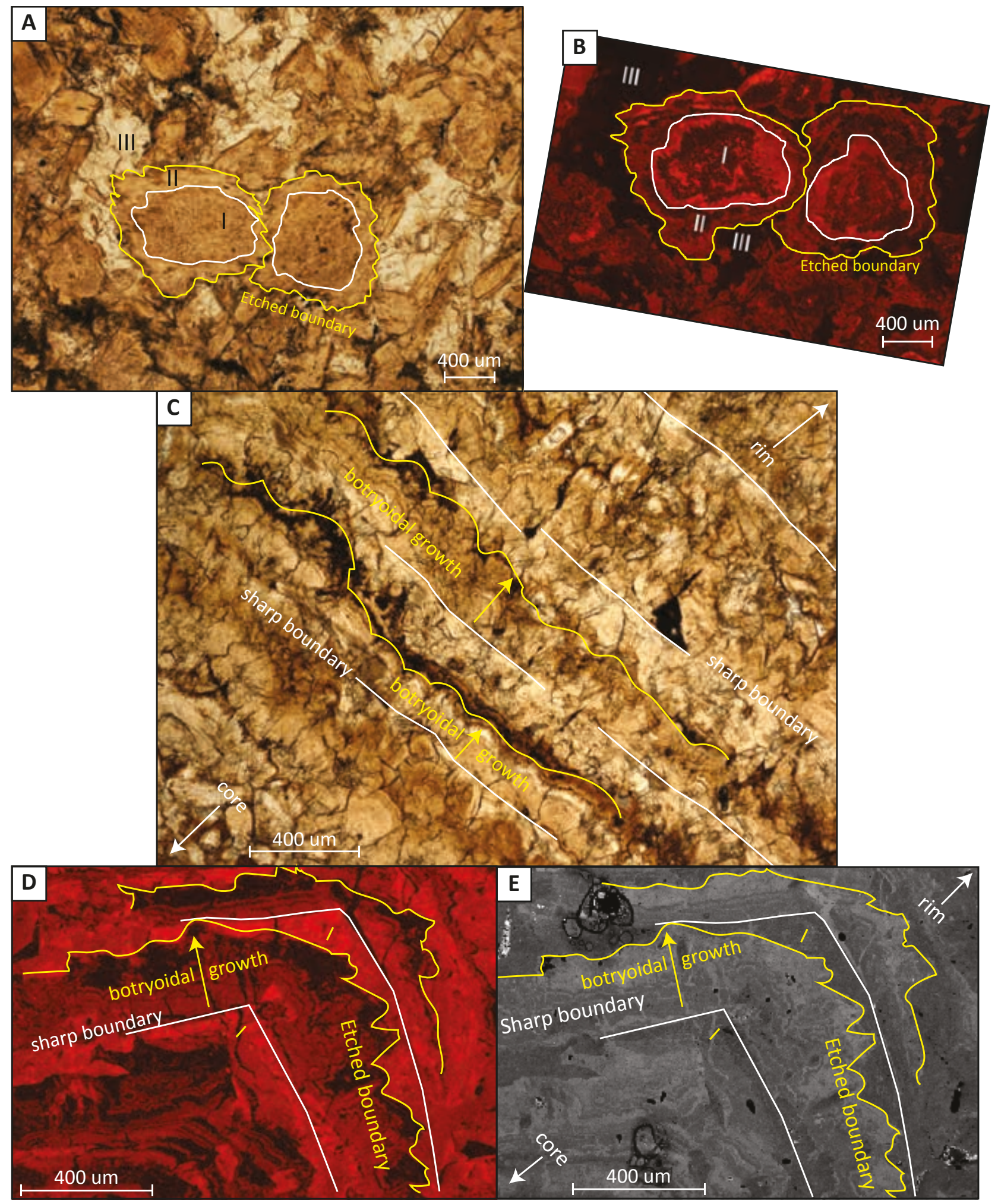

Figure 6. The figure shows the microzonation in glendonites. White outline around Type I primary ikaite-derived calcite (I); yellow outline around Type II calcite (II). Final phase of calcite growth (clear spar) labelled 'III'. (A) Thin-section of an 'unzoned' (not showing macrozonations) glendonite FST753.15 (753.15 m, Festningen Section) under plane-polarised light. (B) CL photomicrograph of the same glendonite thin-section. Microzonation very clear. (C) Thin-section of a macrozoned glendonite, FST411.5C, under plane-polarised light (411.5 m, Festningen Section). Sharp planar surfaces with botryoidal growth of secondary calcite. This suggests that the botryoidal phase always nucleated on a planar surface. (D) Thin-section of macrozoned glendonite FST441.25 (441.25 m, Festningen Section) under CL. Darker = higher iron content, indicating an increasing iron content of calcite as the secondary botryoidal calcite grew. (E) SEM image of the same glendonite. 
that the sediments were kept in shallow diagenetic zones for longer than those of the Carolinefjellet Formation.

\section{Petrology}

There are notable petrological differences between the glendonites from the upper part of the Rurikfjellet Formation and those of the Carolinefjellet Formation, which may be indicative of different conditions prevailing during ikaite growth and transformation to glendonite. The glendonites of the Rurikfjellet Formation show macrozoning, whereas those in the Carolinefjellet Formation are either unzoned or show distinct cores.

All glendonites collected in this study preserve at least three calcite generations. The majority of existing studies on glendonites also show at least 3 generations of calcite growth (David et al., 1905; Boggs, 1972; Larsen, 1994; McLachlan et al., 2001; Huggett et al., 2005; Selleck et al., 2007; Teichert \& Luppold, 2013). Type I calcite, as described in previous studies, is interpreted as the original ikaite-derived calcite (e.g., Larsen, 1994; Huggett et al., 2005; Frank et al., 2008a, b; Teichert \& Luppold, 2013). This primary ikaite-derived calcite is described in well preserved glendonites from around the globe (e.g., Australia, North America, Siberia; Japan, Denmark, U.K.; Larsen, 1994; Greinert \& Derkachev, 2004; Huggett et al., 2005; Selleck et al., 2007; Frank et al., 2008a, b; Teichert \& Luppold, 2013). Type I calcite makes up $31 \%$ by volume of the pseudomorph (since in ikaite, $69 \%$ volume of the structure is water, which is lost when ikaite transforms to calcite, resulting in a $2 / 3^{\text {rd }}$ volume loss; Larsen, 1994; de Lurio \& Frakes, 1999). The botryoidal Type II calcite of this study is interpreted as forming after Type I and before Type III, based on the boundary relationships observed in thin-section examination. Intermediate types of diagenetic calcite described from glendonites in other studies may show similar microscopic concentric zoning, and are described as spherulitic by Huggett et al. (2005) and Frank et al. (2008a, b). Other forms of intermediate diagenetic (Type II) calcite have been described, including radiaxial-fibrous (Frank et al., 2008a, b); fibrous spherulitic (Huggett et al., 2005), forming syntaxial rims (Huggett et al., 2005); microsparitic to sparitic rims and euhedral rims (Greinert \& Derkachev, 2004); and columnar infilling calcite (Teichert \& Luppold, 2013), and it is likely that multiple generations of growth are encompassed by the term 'Type II'. Cathodoluminescence observations in this study suggest that Type II calcite shows an increasing iron content outward, and has etched boundaries with Type III calcite, suggesting that the porewater chemistry was changing as this secondary calcite precipitated, eventually becoming so acidic that dissolution, rather than precipitation, took place. The clear calcite spar observed in the glendonites of this study (Type III) is regarded as the final generation of diagenetic calcite growth (e.g., Huggett et al., 2005; Selleck et al., 2007; Frank et al., 2008a, b; Teichert \&
Luppold, 2013) as it is observed infilling the remaining porosity (see also Kaplan, 1979; Huggett et al., 2005), and is commonly $\mathrm{Fe}$ - and $\mathrm{Mg}$ - rich (this study; Huggett et al., 2005; Frank et al., 2008a, b; Teichert \& Luppold, 2013), or even dolomitised (Huggett et al., 2005). This sparry calcite lacks the brown coloration seen in Type I calcite and secondary, Type II calcite.

The existing model for ikaite-glendonite transformation (e.g., as described by Teichert \& Luppold, 2013, p. 88) models ikaite transforming to calcite whereby the outer parts of the crystal transform before the centre of the crystal (i.e., the outer parts may be calcite which is growing diagenetic calcite rims whilst the centre remains stable). This model largely fits with observations of this study of the unzoned glendonites (and those showing distinctive cores and rims), although does not explain the observed etched boundaries on the Type II calcite (Fig. $6)$.

Coupled with the fact that some glendonites are found inside carbonate concretions (a phenomenon also observed for glendonites from other locations (Boggs, 1972; Huggett et al., 2005; Teichert \& Luppold, 2013), the presence of etched boundaries on less luminescent (interpreted as increasingly iron-rich) Type II calcite suggests that as the Type II calcite precipitated the glendonites were then moving deeper into, then beyond, the sulphate reduction zone, under decreasing rates of sulphate reduction, as suggested by Krajewski \& Luks (2003). The pyrite observed in the glendonites is likely to have formed whilst this local dissolution was occurring (Krajewski \& Luks, 2003). This suggests that the secondary calcite (Type II) growth onto transformed-ikaite calcite (Type I) occurred soon after ikaite transformed to calcite, whilst the pseudomorphs were still in uncompacted sediments, and in the sulphate reduction zone.

In some studies it has been observed that ikaite breaks down first to a mixture of vaterite (a metastable polymorph of $\mathrm{CaCO}_{3}$, with the highest molar volume of the three anhydrous $\mathrm{CaCO}_{3}$ polymorphs) (e.g., Shaikh, 1990; Ito, 1998; Tang et al., 2009) and calcite. Tang et al. (2009) suggested that the vaterite is from solidstate transformation of ikaite and the calcite is from dissolution of the ikaite and subsequent precipitation as calcite. No vaterite has been reported in glendonites, and it is unclear at what stage in the ikaite-to-glendonite transformation the vaterite transforms to calcite. Given the low stability of vaterite it can hence only be inferred that as ikaite destabilises it converts to vaterite + calcite + water (Fig. 7). Vaterite would then dissolve and reprecipitate as calcite (Type I calcite), the $\mathrm{CaCO}_{3}$ source being the parent ikaite. In some cases only the margins of the ikaite crystal destabilise, leaving a core of ikaite in the crystal centre (Fig. 7B). As observed in this study, Type II calcite grows on the Type I calcite (Figs. 6 \& 7). The $\mathrm{CaCO}_{3}$ source for the Type II calcite 




B MACRO-ZONED GLENDONITES

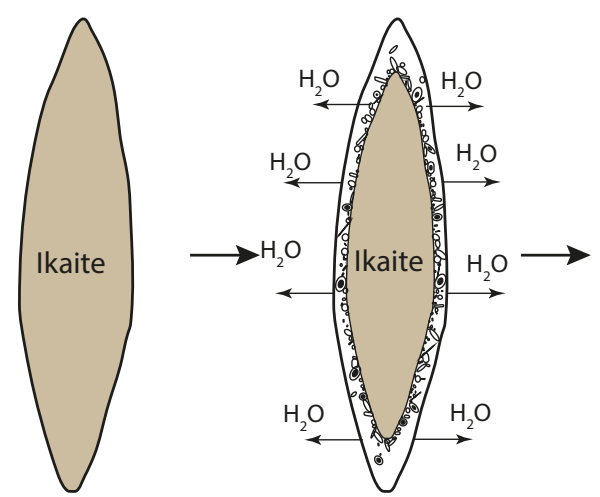

Conditions change slightly; outside edge becomes unstable; Ikaite $\longrightarrow$ vaterite+calcite+water vaterite $\longrightarrow$ calcite

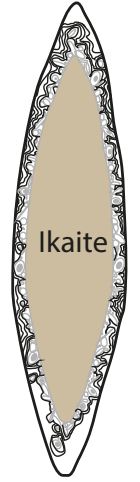

Calcite cement grows onto transformed ikaite (Type II onto Type I)

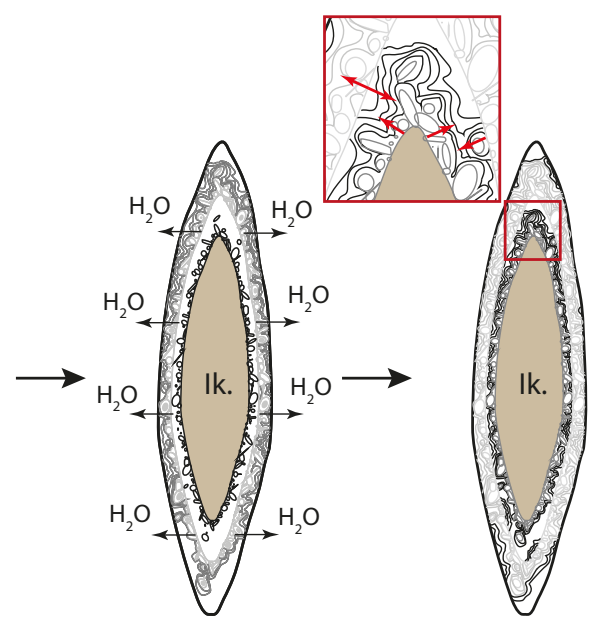

Next layer of ikaite become unstable and transforms; cement continues growing onto transformed ikaite, both in core-to-rim and rim-to-core directions
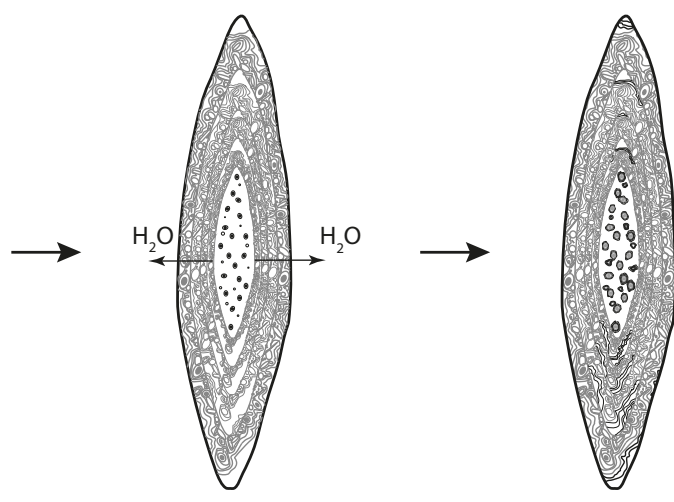

Eventually the core of ikaite transforms. Continued growth of Type II calcite.

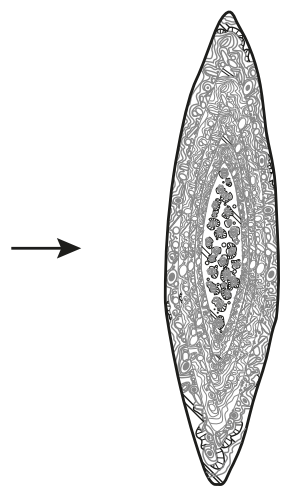

Etching, final sparry calcite (Type III) precipitates later.

Figure 7. Figure showing the improved models for ikaite-to-glendonite transformation based on the observations and data gathered in this study, modified after Teichert \& Luppold (2013) and Frank et al. (2008a). (A) Model for ikaite-to-glendonite transformation for unzoned glendonites, whereby ikaite breaks down to a mix of vaterite, calcite and water, and the vaterite rapidly transforms to calcite. This transformed ikaite-calcite is still sitting in the sulphate reduction zone, and experiences rapid diagenetic calcite overgrowth. This ceases when the sediments in which it lies move out of the sulphate reduction zone, and partial dissolution may occur at the edges of the diagenetic calcite. An unknown amount of time later, late-stage sparry calcite infills any voids. (B) Model for ikaite-to-glendonite transformation for macrozoned glendonites, whereby oscillations in conditions resulting in the slow, progressive breakdown of the ikaite crystal, from the outside in. 
is likely the pore water in the sediments. Next, the core of ikaite destabilises to vaterite which then converts to calcite (Fig. 7B). Cements continue to grow on the first generation of Type II calcite, and may begin to grow on the newly-formed Type I calcite in the core. As the sediments in which the pseudomorphs are sitting become progressively buried, they eventually pass out of the sulphate reduction zone. Conditions then become unfavourable for calcite precipitation, as evidenced by etched boundaries on the Type II calcite (Fig. 7). An unknown length of time later, diagenetic sparry calcite (Type III) fills the remaining voids (Fig. 7).

For glendonites with distinct macrozoning, it is hypothesised that conditions (thermal and chemical) oscillate around the ikaite stability field, resulting in the outside edge of the crystal becoming unstable while the rest of the crystal remains stable. The same processes occur whereby the ikaite progressively destabilises from the outside in, only at a slower rate than that which generated the glendonites with the distinct cores (Fig. 7C). Alternatively, it could be postulated that the crystal (ikaite or calcite) grew outward in progressive zones, as the fabric shows elements of both core-to-rim and rimto-core growth. However, if the zoning occurred during ikaite growth, it is unlikely that it would be preserved after ikaite transformed, given the $2 / 3^{\text {rd }}$ volume loss from the ikaite-to-calcite (via vaterite) transformation. If ikaite transformed to calcite, which then experienced slow zoned growth outward from the outer edge of the pseudomorph, the fabric in the centre of the crystals would be expected to show blebs of original 'ikaite' calcite, which would not be seen in the zones as these grew after transformation. Given that the cores show the same structural elements as the rims, it is more parsimonious to conclude that the zoning must be due to the slow breakdown of ikaite from the outside in, with syntransformational growth of secondary (Type II) calcite onto newly-formed calcite (Type I; e.g., Figs. 6 \& 7). This agrees with the findings of Teichert \& Luppold (2013), who concluded that the ikaite remains stable in the centre of the crystal for longer than in the margins.

It is hypothesised here that it is the rate and oscillatory nature of the chemical and thermal conditions that determine whether the crystal became zoned (very slow rate of transformation; oscillatory conditions; Fig. 7C), has a distinct core/rim (Fig. 7B), or shows no macrozoning at all (Fig. 7A). This is supported by the observation that the macrozoned glendonites are found in the more condensed Kikutodden Member of the Rurikfjellet Formation, where sedimentation rates were low, whereas the unzoned glendonites are found in the Carolinefjellet Formation, which is characterised by high sedimentation rates. Thus, the glendonites of the Kikutodden Member sat for longer in the sulphate reduction zone, where chemical conditions appear to have oscillated between ikaite stability and instability, whereas those of the Carolinefjellet Formation were moved through the sulphate reduction zone more rapidly and transformed wholly to calcite before secondary diagenetic calcite types were precipitated.

\section{Stable isotopes of glendonites}

The $\delta^{13} \mathrm{C}$ and $\delta^{18} \mathrm{O}$ data show a strong negative correlation in both ancient glendonites and in cannonball concretions (e.g., Scotchman 1991; Krajewski \& Luks, 2003) (Figs. $3 \& 8$ ). This is contrary to the positive trend seen in altered and pristine belemnite calcite, and calcite cement, whereby $\delta^{13} \mathrm{C}$ is pushed to lighter values with time (e.g., typical meteoric diagenesis; Price \& Nunn, 2010). This negative trend (Fig. 8) in glendonites and concretions reflects the evolution of the carbonate through the various paragenetic stages; later carbonate growth shows lighter $\delta^{18} \mathrm{O}$ but heavier $\delta^{13} \mathrm{C}$, reflecting the change in carbon source with depth from microbial organic matter breakdown in the sulphate reduction zone towards marine DIC sources (e.g., Scotchman, 1991; Krajewski \& Luks, 2003; Selleck et al., 2007; Frank et al., 2008b). For Recent (Holocene age) glendonites, which lack the later generations of diagenetic calcite, $\delta^{13} \mathrm{C}$ values are within the range of organic matter to methane, whereas oxygen isotope values reflect a seawater or meteoric source (Fig. 8). Since bulk glendonites were used, it is noted that those showing heavier $\delta^{13} \mathrm{C}$ and lighter $\delta^{18} \mathrm{O}$ contain more (late-stage) sparry calcite, based on petrographic observations.

The glendonites of Spitsbergen show a broad range of $\delta^{13} \mathrm{C}$ values, reflecting both variation in carbon source and proportion of later diagenetic calcite types. The lowest $\delta^{13} \mathrm{C}$ glendonite value is $-30.9 \%$ and well within the range expected if methane was an important carbon source. However, the other glendonites analysed in this study do not show convincing methane $\delta^{13} \mathrm{C}$ values, and, given the similarity in trends between cannon-ball concretion calcite types and separated glendonite types as evidenced in previous studies (Scotchman, 1991; Krajewski \& Luks, 2003; Selleck et al., 2007; Frank et al., 2008a, b), we argue that methane is not necessary as a driver of glendonite formation. No carbonates were found showing the highly positive 'residual' $\delta^{13} \mathrm{C}$ values after microbial methanogenesis (e.g., a $\delta^{13} \mathrm{C}$ range of 1 to $15 \%$, Irwin et al., 1977; Morales et al., 2017). Our interpretation of a mixed source of carbon is further supported by the fact that Recent transformed ikaite $\delta^{13} \mathrm{C}$ values span a broad range, from $<-30$ to $>-20 \%$, reflecting both organic matter and methane sources (Fig. 8) (Suess et al., 1982; Stein \& Smith, 1986; Jansen et al., 1987; Zabel \& Schultz, 2001). 


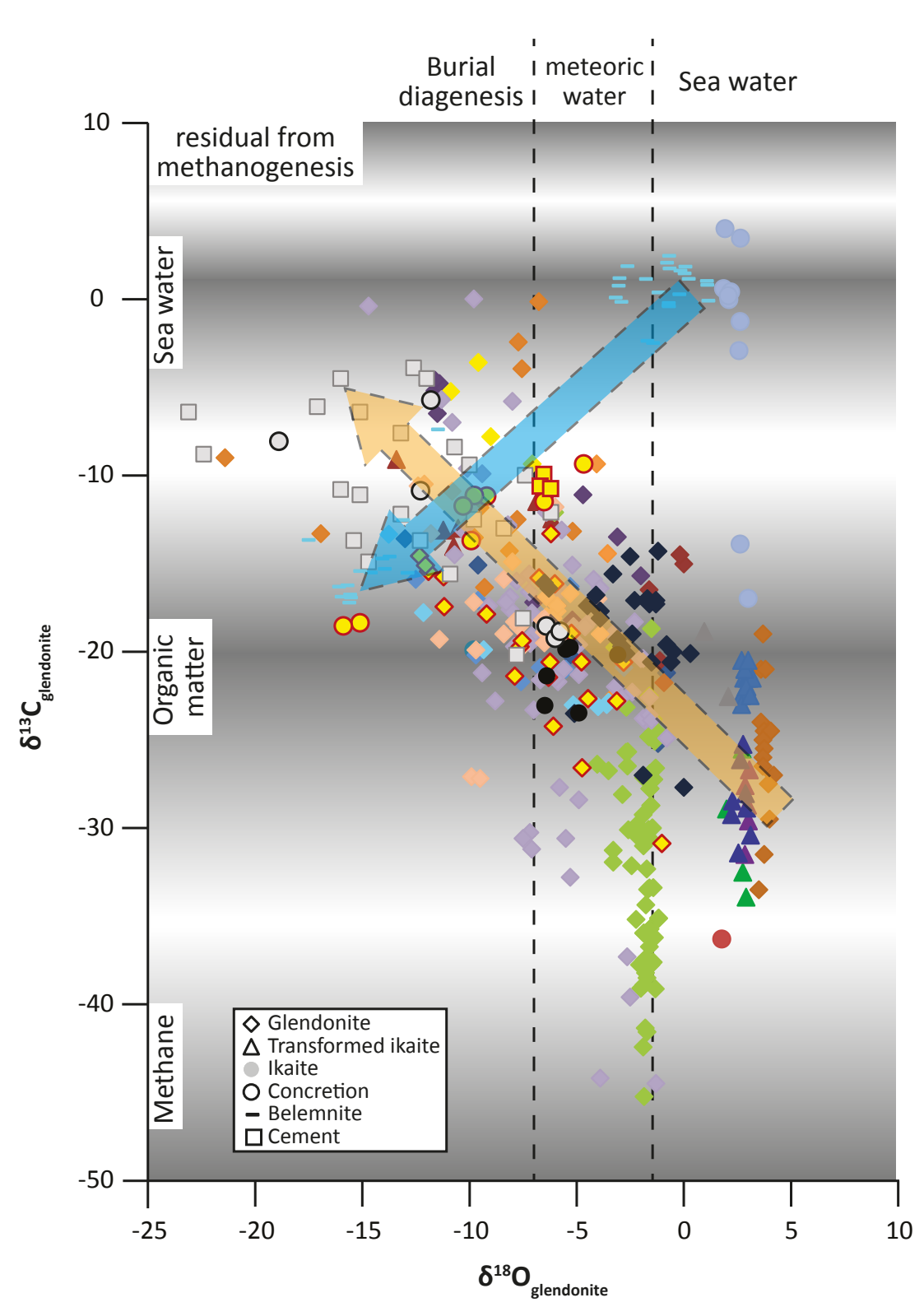

\section{Recent}

- Whiticar and Suess (1998)

Lu et al. (2012) hydrated

- Schubert et al. (1996) hydrated

$\Delta$ Greinert and Derkachev (2004)

$\Delta$ Jansen et al. (1987)

Zabel and Schultz (2001)

$\Delta$ Stein and Smith (1986)

$\triangle$ Suess et al. (1982)

Greinert and Derkachev (2004)

Cenozoic

- Whiticar and Suess (1998)

Boggs (1972)

- Spielhagen and Tripati (2009)

Cretaceous Svalbard

$\diamond$ glendonite, THIS STUDY

O concretion, THIS STUDY

$\square$ cement, THIS STUDY

glendonite, Price and Nunn (2010)

- belemnite, Price and Nunn (2010)

concretion body,

Krajewski and Luks (2003)

concretion spar,

Krajewski and Luks (2004)

\section{Mesozoic}

Rogov et al. (2017)

Grasby et al. (2017)

$\checkmark$ Teichert and Luppold (2013)

Morales et al. (2017)

$\checkmark$ de Lurio and Frakes (1999)

\section{Paleozoic}

- Huggett et al. (2005)

Selleck et al. (2007)

Selleck et al. (2007); amber calcite separate from glendonite

- Frank et al. (2008b); ikaite replacement phase

$\square$ Frank et al. (2008b); glendonite cement

Figure 8. The glendonite and concretionary calcite stable isotope data gathered in this study compared to Svalbard belemnite calcite (Price \& Nunn, 2010), Svalbard cannon-ball concretion (Krajewski \& Luks, 2003), glendonite, transformed ikaite and ikaite $\delta^{13} \mathrm{C}$ and $\delta^{18} \mathrm{O}$ data from previous studies (sources cited on figure). The $\delta^{13} \mathrm{C}$ ranges for methane, organic carbon and seawater (as given by Campbell, 2006) are indicated by grey shading. The $\delta^{18} \mathrm{O}$ ranges for sea-water, meteoric water, and those associated with burial diagenesis (as discussed in Campbell, 2006), are indicated by dashed lines. The blue arrow indicates evolutionary trends for typical meteoric diagenesis (heavy $\delta^{13} \mathrm{C}$ and $\delta^{18} \mathrm{O}$ to light $\delta^{13} \mathrm{C}$ and light $\delta^{18} \mathrm{O}$ with increasing burial depth and diagenetic alteration); the beige arrow shows sulphate reduction zone evolutionary trends from light $\delta^{13} \mathrm{C}$ and heavy $\delta^{18} \mathrm{O}$ to heavier $\delta^{13} \mathrm{C}$ and lighter $\delta^{18} \mathrm{O}$

\section{Conclusions}

This study advances the existing model for ikaite to glendonite transformation, explaining the observations of etched boundaries and the different fabrics observed between the macrozoned glendonites of the Kikutodden Member and the unzoned glendonites of the Carolinefjellet Formation. We explain the different fabrics observed between the Rurikfjellet Formation and the Carolinefjellet Formation glendonites by the difference in sedimentation rates: the low sedimentation rates in the upper Rurikfjellet Formation meant that the ikaite/glendonite remained in the sulphate reduction zone for longer, such that the transformation from ikaite to glendonite was gradual, with conditions oscillating between ikaite stability and instability, resulting in the macrozoned fabrics observed in the glendonites. Those of the Carolinefjellet Formation underwent rapid transformation from ikaite to glendonite, owing to elevated sedimentation rates causing the ikaite/ glendonite to move out of the sulphate reduction zone (where ikaite is metastable) more quickly. 
This new study suggests that ancient bulk glendonite $\delta^{18} \mathrm{O}$ values cannot be used for palaeotemperature reconstructions, and has significant implications for using glendonites as quantitative palaeothermometers: if microsampling without heating could be carried out such that only the 'primary' calcite (Type I) were sampled, this could then be used for $\delta^{18} \mathrm{O}$ or clumped isotope palaeothermometry, reintroducing glendonites as a palaeothermometry tool.

Acknowledgements. We are grateful to journal reviewers Jenny Huggett and Stephen Grasby for insightful comments on an earlier version of the paper. We acknowledge the support from a University of Plymouth $\mathrm{PhD}$ studentship to M.L. Vickers, and grants received from the Geological Society of London (Robert Scott Memorial Award), American Association of Petroleum Geologists (Grant-in-Aid) and the British Sedimentological Research Group (Gill Harwood Memorial Fund), without whom this research would not have been possible. We acknowledge support from Arctic Adventures AS for arranging the fieldwork logistics, and we thank the Governor of Svalbard for granting permission to carry out the fieldwork. We would particularly like to extend thanks to Meriel Fitzpatrick for assistance in the field, to Marc Davies for analysis of the carbonates, and to Peter Bond and the Plymouth Electron Microscopy Centre.

\section{REFERENCES}

Barnaby, R.J. \& Rimstidt, J.D. 1989: Redox conditions of calcite cementation interpreted from $\mathrm{Mn}$ and Fe contents of authigenic calcites. Geological Society of America Bulletin 101, 795-804. https://doi.org/10.1130/0016-7606(1989)101<0795:RCOCCI>2.3.CO;2.

Bischoff, J.L., Fitzpatrick. J.A. \& Rosenbauer. R.J. 1993: The Solubility and Stabilization of Ikaite $(\mathrm{CaCO} 3.6 \mathrm{H} 2 \mathrm{O})$ from $0^{\circ}$ to $25^{\circ} \mathrm{C}$ : Environmental and Paleoclimatic Implications for Thinolite Tufa. The Journal of Geology 101, 21-33. https://doi.org/10.1086/648194.

Boggs, S. 1972: Petrography and geochemistry of rhombic, calcite pseudomorphs from mid-Tertiary mudstones of the Pacific Northwest, USA. Sedimentology 19, 219-235.

https://doi.org/10.1111/j.1365-3091.1972.tb00022.x.

Boucot, A.J., Xu, C. \& Scotese, R. 2013: Phanerozoic Paleoclimate: An Atlas of Lithologic Indicators of Climates. Society of Paleontologists and Mineralogists (SEPM) Concepts in Sedimentology and Paleontology, No. 11: Map Folio, 478 pp. ISBN 978-1-56576-282-4.

Buchardt, B., Israelson, C., Seaman, P. \& Stockmann, G. 2001: Ikaite tufa towers in Ikka Fjord, southwest Greenland: their formation by mixing of seawater and alkaline spring water. Journal of Sedimentary Research 71, 176-189. https://doi.org/10.1306/042800710176.

Campbell, K.A. 2006: Hydrocarbon seep and hydrothermal vent paleoenvironments and paleontology: past developments and future research directions. Palaeogeography, Palaeoclimatology, Palaeoecology 232, 362-407. https://doi.org/10.1016/j.palaeo.2005.06.018.

Dana, J.D. 1849: Geology of the United States - Exploring expedition during the years 1836,1840,1841,1842, under the command of Charles Wilkes. C. Sherman, Philadelphia, 76 pp.

David, T.W.E., Taylor, T.G., Woolnough, W.G. \& Foxall, H.G. 1905: Occurrence of the pseudomorph glendonites in New South Wales. Records of the Geological Survey of New South Wales 8, 163-179.

De Lurio, J.L. \& Frakes, L.A. 1999: Glendonites as a paleoenvironmental tool: implications for early Cretaceous high latitude climates in Australia. Geochimica et Cosmochimica Acta 63, 1039-1048. https://doi.org/10.1016/S0016-7037(99)00019-8.
Dieckmann, G.S., Nehrke, G., Papadimitriou, S., Göttlicher, J., Steininger, R., Kennedy, H., Wolf-Gladrow, D. \& Thomas, D.N. 2008: Calcium carbonate as ikaite crystals in Antarctic sea ice. Geophysical Research Letters 35. https://doi.org/10.1029/2008GL033540.

Dieckmann, G., Nehrke, G., Uhlig, C., Göttlicher, J., Gerland, S., Granskog, M. \& Thomas D. 2010: Ikaite $\left(\mathrm{CaCO}_{3} .6 \mathrm{H}_{2} \mathrm{O}\right)$ discovered in Arctic sea ice. The Cryosphere 4, 227-230. https://doi.org/10.5194/tc-4-227-2010.

Frank, T.D., Thomas, S.G. \& Fielding, C.R. 2008a: Glendonites as Paleoclimatic and Paleoceanographic Indicators: A Case Study from the Glacially Influenced Permian System of Eastern Australia. Search and Discovery Article (50129).

Frank, T.D., Thomas, S.G. \& Fielding C.R. 2008b: On using carbon and oxygen isotope data from glendonites as paleoenvironmental proxies: a case study from the Permian system of eastern Australia. Journal of Sedimentary Research 78, 713-723. https://doi.org/10.2110/jsr.2008.081.

Grasby, S.E., McCune, G.E., Beauchamp, B. \& Galloway, J.M. 2017: Lower Cretaceous cold snaps led to widespread glendonite occurrences in the Sverdrup Basin, Canadian High Arctic. Geological Society of America Bulletin 129, 771-787. https://doi.org/10.1130/B31600.1.

Greinert, J. \& Derkachev, A. 2004: Glendonites and methane-derived $\mathrm{Mg}$-calcites in the Sea of Okhotsk, Eastern Siberia: implications of a venting-related ikaite/glendonite formation. Marine Geology 204, 129-144. https://doi.org/10.1016/S0025-3227(03)00354-2.

Grundvåg, S.A. \& Olaussen, S. 2017: Sedimentology of the Lower Cretaceous at Kikutodden and Keilhaufjellet, southern Spitsbergen: implications for an onshore-offshore link. Polar Research 36. https://doi.org/10.1080/17518369.2017.1302124.

Hu, Y.B., Wolf-Gladrow, D.A., Dieckmann, G.S., Völker, C. \& Nehrke, G. 2014: A laboratory study of ikaite $(\mathrm{CaCO} 3.6 \mathrm{H} 2 \mathrm{O})$ precipitation as a function of $\mathrm{pH}$, salinity, temperature and phosphate concentration. Marine Chemistry 162, 10-18. https://doi.org/10.1016/j.marchem.2014.02.003.

Huggett, J., Schultz, B., Shearman, D. \& Smith, A. 2005: The petrology of ikaite pseudomorphs and their diagenesis. Proceedings of the Geologists' Association 116, 207-220. https://doi.org/10.1016/S0016-7878(05)80042-2.

Irwin, H., Curtis, C. \& Coleman, M. 1977: Isotopic evidence for source of diagenetic carbonates formed during burial of organic-rich sediments. Nature 269, 209-213. https://doi.org/10.1038/269209a0.

Ito, T. 1998: Factors controlling the transformation of natural ikaite from Shiowakka, Japan. Geochemical journal 32, 267-273. https://doi.org/10.2343/geochemj.32.267.

Jansen, J., Woensdregt, C., Kooistra, M. \& Van Der Gaast, S. 1987: Ikaite pseudomorphs in the Zaire deep-sea fan: an intermediate between calcite and porous calcite. Geology 15, 245-248. https://doi.org/10.1130/0091-7613(1987)15<245:IPITZD>2.0.CO;2.

Kaplan, M. 1979: Calcite pseudomorphs (pseudogaylussite, jarrowite, thinolite, glendonite, gennoishi, White Sea hornlets) in sedimentary rocks: origins of the pseudomorphs. Lithology and Mineral Resources 14, 623-636.

Krajewski, K.P. \& Luks, B. 2003: Origin of 'cannon-ball' concretions in the Carolinefjellet Formation (Lower Cretaceous), Spitsbergen. Polish Polar Research 24, 217-242.

Larsen, D. 1994: Origin and paleoenvironmental significance of calcite pseudomorphs after ikaite in the Oligocene Creede Formation, Colorado. Journal of Sedimentary Research 64, 593-603.

Lennie, A., Tang, C. \& Thompson, S. 2004: The structure and thermal expansion behaviour of ikaite, $\mathrm{CaCO}_{3} \cdot 6 \mathrm{H}_{2} \mathrm{O}$, from $\mathrm{T}=114$ to $\mathrm{T}=$ 293 K. Mineralogical Magazine 68, 135-146. https://doi.org/10.1180/0026461046810176.

Lu, Z., Rickaby, R.E., Kennedy, H., Kennedy, P., Pancost, R.D., Shaw, S., Lennie, A., Wellner, J. \& Anderson, J.B. 2012: An ikaite record of late Holocene climate at the Antarctic Peninsula. Earth and Planetary Science Letters 325, 108-115. https://doi.org/10.1016/j.epsl.2012.01.036. 
Machel, H.G. \& Burton E.A. 1991: Factors governing cathodoluminescence in calcite and dolomite and their implications for studies of carbonate diagenesis. In Barker, C.E. \&

Kopp, O.C. (eds.): Luminescence microscopy and spectroscopy: qualitative and quantitative applications. Society for Sedimentary Geology Short Course 25, pp. 9-25.

Maher, H.D., Hays, T., Shuster, R. \& Mutrux, J. 2004: Petrography of Lower Cretaceous sandstones on Spitsbergen. Polar Research 23, 147-165. https://doi.org/10.3402/polar.v23i2.6276.

Major, H., Haremo, P., Dallmann, W. K. \& Andresen, A. 2000: Geological map of Svalbard 1:100000, sheet C9G Adventdalen (revised after Major 1964). Norsk Polarinstitutt Temakart, 31.

Marland, G. 1975: The stability of $\mathrm{CaCO}_{3} \cdot 6 \mathrm{H}_{2} \mathrm{O}$ (ikaite). Geochimica et Cosmochimica Acta 39, 83-91.

https://doi.org/10.1016/0016-7037(75)90186-6.

McLachlan, I., Tsikos, H. \& Cairncross, B. 2001: Glendonites (pseudomorphs after ikaite) in late carboniferous Marine Dwyka beds in Southern Africa. South African Journal of Geology 104, 265272. https://doi.org/10.2113/1040265.

Midtkandal, I., Nystuen, J.P., Nagy, J. \& Mørk, A. 2008: Lower Cretaceous lithostratigraphy across a regional subaerial unconformity in Spitsbergen: the Rurikfjellet and Helvetiafjellet formations. Norwegian Journal of Geology 88, 287-304.

Morales, C., Rogov, M., Wierzbowski, H., Ershova, V., Suan, G., Adatte, T., Follmi, K.B., Tegelaar, E., Reichart, G.J. \& de Lange, G.J. 2017: Glendonites track methane seepage in Mesozoic polar seas. Geology 45, 503-506. https://doi.org/10.1130/G38967.1.

Mørk, A, Dallmann, W.K., Dypvik, H., Johannessen, E.P., Larssen, G.B., Nagy, J., Nøttvedt, A., Olaussen, S., Pčelina, T.M. \& Worsley, D. 1999: Mesozoic Lithostratigraphy. In Dallmann, W.K. (ed.): Lithostratigraphic Lexicon of Svalbard, Norwegian Polar Institute, Tromsø, pp. 127-214.

Pauly, H. 1963: 'Ikaite', a New Mineral from Greenland. Arctic 16, $263-$ 264. https://doi.org/10.14430/arctic3545.

Price, G.D. \& Nunn, E.V. 2010: Valanginian isotope variation in glendonites and belemnites from Arctic Svalbard: Transient glacial temperatures during the Cretaceous greenhouse. Geology 38, 251254. https://doi.org/10.1130/G30593.1.

Qu, Y., Teichert, B.M.A., Birgel, D., Goedert, J.L. \& Peckmann, J. 2017: The prominent role of bacterial sulfate reduction in the formation of glendonite: a case study from Paleogene marine strata of western Washington State. Facies 63, 1-16. https://doi.org/10.1007/s10347-017-0492-1.

Rickaby, R., Shaw, S., Bennitt, G., Kennedy, H., Zabel, M. \& Lennie, A. 2006: Potential of ikaite to record the evolution of oceanic $\delta^{18} \mathrm{O}$. Geology 34, 497-500. https://doi.org/10.1130/G22413.1.

Rogov, M.A., Ershova, V.B., Shchepetova, E.V., Zakharov, V.A., Pokrovsky, B.G. \& Khudoley, A.K. 2017: Earliest Cretaceous (late Berriasian) glendonites from Northeast Siberia revise the timing of initiation of transient Early Cretaceous cooling in the high latitudes. Cretaceous Research 71, 102-112.

https://doi.org/10.1016/j.cretres.2016.11.011.

Schubert, C., Nürnberg, D., Scheele, N., Pauer, F. \& Kriews, M. 1997: 13C isotope depletion in ikaite crystals: evidence for methane release from the Siberian shelves? Geo-Marine Letters 17, 169-174. https://doi.org/10.1007/s003670050023.

Scotchman, I. 1991: The geochemistry of concretions from the Kimmeridge Clay Formation of southern and eastern England. Sedimentology 38, 79-106. https://doi.org/10.1111/j.1365-3091.1991.tb01856.x.

Selleck, B.W., Carr, P.F. \& Jones, B.G. 2007: A review and synthesis of glendonites (pseudomorphs after ikaite) with new data: assessing applicability as recorders of ancient coldwater conditions. Journal of Sedimentary Research 77, 980-991. https://doi.org/10.2110/jsr.2007.087.

Shaikh, A. 1990: A new crystal growth form of vaterite, $\mathrm{CaCO}_{3}$. Journal of applied crystallography 23, 263-265.

https://doi.org/10.1107/S0021889890002485.
Spielhagen, R.F. \& Tripati, A. 2009: Evidence from Svalbard for nearfreezing temperatures and climate oscillations in the Arctic during the Paleocene and Eocene. Palaeogeography, Palaeoclimatology, Palaeoecology 278, 48-56.

https://doi.org/10.1016/j.palaeo.2009.04.012.

Stein, C. \& Smith, A. 1985: Authigenic carbonate nodules in the Nankai Trough, Site 583. Initial reports of the deep sea drilling project 77 , 659-668.

Suess, E., Balzer, W., Hesse, K.F., Müller, P., Ungerer, C. \& Wefer, G. 1982: Calcium carbonate hexahydrate from organic-rich sediments of the antarctic shelf: Precursors of glendonites. Science 216, 1128-1131. https://doi.org/10.1126/science.216.4550.1128.

Swainson, I.P. \& Hammond, R.P. 2001: Ikaite, $\mathrm{CaCO}_{3} \cdot 6 \mathrm{H}_{2} \mathrm{O}$ : Cold comfort for glendonites as paleothermometers. American Mineralogist 86, 1530-1533. https://doi.org/10.2138/am-2001-11-1223.

Tang, C., Thompson, S., Parker, J., Lennie, A., Azough, F. \& Kato, K. 2009: The ikaite-to-vaterite transformation: new evidence from diffraction and imaging. Journal of Applied Crystallography 42, 225-233. https://doi.org/10.1107/S0021889809005810.

Teichert, B. \& Luppold, F. 2013: Glendonites from an Early Jurassic methane seep-Climate or methane indicators? Palaeogeography, Palaeoclimatology, Palaeoecology 390, 81-93. https://doi.org/10.1016/j.palaeo.2013.03.001.

Vickers, M.L., Price, G.D., Jerrett, R.M. \& Watkinson, M. 2016: Stratigraphic and geochemical expression of Barremian-Aptian global climate change in Arctic Svalbard. Geosphere 12, 1594-1605. https://doi.org/10.1130/GES01344.1.

Vickers, M. 2017: Stratigraphic and geochemical expression of Early Cretaceous environmnetal change in Arctic Svalbard. PhD thesis, University of Plymouth, $275 \mathrm{pp}$.

Whiticar, M.J. \& Suess, E. 1998: The cold carbonate connection between Mono Lake, California and the Bransfield Strait, Antarctica. Aquatic Geochemistry 4, 429-454. https://doi.org/10.1023/A:1009696617671.

Zabel, M. \& Schulz, H.D. 2001: Importance of submarine landslides for non-steady state conditions in pore water systems-lower Zaire (Congo) deep-sea fan. Marine Geology 176, 87-99. https://doi.org/10.1016/S0025-3227(01)00164-5.

Zhou, X., Lu, Z., Rickaby, R.E., Domack, E.W., Wellner, J.S. \& Kennedy, H.A. 2015: Ikaite abundance controlled by porewater phosphorus level: potential links to dust and productivity. The Journal of Geology 123, 269-281. https://doi.org/10.1086/681918. 